\title{
A Review of Organic Farming for Sustainable Agriculture in Northern India
}

\author{
S. K. Yadav, Subhash Babu, M. K. Yadav, Kalyan Singh, G. S. Yadav, and Suresh Pal \\ Institute of Agricultural Sciences, Banaras Hindu University, Varanasi, Uttar Pradesh 221005, India \\ Correspondence should be addressed to S. K. Yadav; sanjaybhu05@rediffmail.com
}

Received 29 March 2013; Accepted 16 May 2013

Academic Editor: A. V. Barker

Copyright (C) 2013 S. K. Yadav et al. This is an open access article distributed under the Creative Commons Attribution License, which permits unrestricted use, distribution, and reproduction in any medium, provided the original work is properly cited.

In the post independence period, the most important challenge in India has been to produce enough food for the growing population. Hence, high-yielding varieties are being used with infusion of irrigation water, fertilizers, or pesticides. This combination of high-yielding production technology has helped the country develop a food surplus as well as contributing to concerns of soil health, environmental pollution, pesticide toxicity, and sustainability of agricultural production. Scientists and policy planners are, therefore, reassessing agricultural practices which relied more on biological inputs rather than heavy usage of chemical fertilizers and pesticides. Organic farming can provide quality food without adversely affecting the soil's health and the environment; however, a concern is whether large-scale organic farming will produce enough food for India's large population. Certified organic products including all varieties of food products including basmati rice, pulses, honey, tea, spices, coffee, oilseeds, fruits, cereals, herbal medicines, and their value-added products are produced in India. Non edible organic products include cotton, garments, cosmetics, functional food products, body care products, and similar products. The production of these organic crops and products is reviewed with regard to sustainable agriculture in northern India.

\section{Introduction}

The organic movement in India has its origin in the work of Howard [1] who formulated and conceptualized most of the views which were later accepted by those people who became active in this movement. Organic farming is a production system which avoids, or largely excludes, the use of synthetic fertilizers, pesticides, growth regulators, and livestock feed additives. The objectives of environmental, social, and economic sustainability are the basics of organic farming [2]. The key characteristics include protecting the long-term fertility of soils by maintaining organic matter levels, fostering soil biological activity, careful mechanical intervention, nitrogen self-sufficiency through the use of legumes and biological nitrogen fixation, effective recycling of organic materials including crop residues and livestock wastes and weed, and diseases and pest control relying primarily on crop rotations, natural predators, diversity, organic manuring, and resistant varieties. A great emphasis is placed to maintain the soil fertility by returning all the wastes to it chiefly through compost to minimize the gap between NPK addition and removal from the soil [3]. Today, the burgeoning population pressure has forced many countries to use chemicals and fertilizers to increase the farm productivity for meeting their ever-increasing food requirements. The prolonged and over usage of chemicals has, however, resulted in human and soil health hazards along with environmental pollution. Farmers in the developed countries are, therefore, being encouraged to convert their existing farms into organic farm.

The key factors affecting consumer demand for organic food is the health consciousness and the willingness of the public to pay for the high-priced produce. In general, consumers of organic products are an affluent, educated, and health conscious group spurred by strong consumer demand, generous price premium, and concerns about the environment. Because of these hidden benefits, conventional growers are turning to organic farming. In Europe, government policies aim to stimulate the organic sector through subsidies, consumer education, and support in the form of research, education, and marketing. Agricultural practices of India date back to more than 4000 years, and organic farming is very much native to this country. As mentioned 
in Arthashastra, farmers in the Vedic period possessed a fair knowledge of soil fertility, seed selection, plant protection, sowing seasons, and sustainability of crops in different lands [4]. The farmers of ancient India adhered to the natural laws and this helped in maintaining the soil fertility over a relatively longer period of time [5].

\section{Organic Sources of Plant Nutrients}

At present, most optimistic estimates show that about 25-30 percent of nutrient needs of Indian agriculture can be met by various organic sources. Supplementation of entire $\mathrm{N}$ through FYM sustains crop productivity at more than use of conventional N fertilizers. Since the estimates of NPK availability from organic sources are based on total nutrient content, efficiency of these sources to meet the nutrient requirement of crops is not as assured as mineral fertilizers, but the joint use of chemical fertilizers along with various organic sources is capable of sustaining higher crop productivity, improving soil quality, and productivity on long-term basis [3]. These organic sources besides supplying $\mathrm{N}, \mathrm{P}$, and $\mathrm{K}$ also make unavailable sources of elemental nitrogen, bound phosphates, micronutrients, and decomposed plant residues into an available form to facilitate the plants to absorb the nutrients. Application of organic sources encouraged the growth and activity of mycorrhizae and other beneficial organisms in the soil and is also helpful in alleviating the increasing incidence or deficiency of secondary and micronutrients and is capable of sustaining high crop productivity and soil health [6]. The farmers can in turn, get good remuneration from organically produced crops and if included in high value crop rotations, that is, aromatic rice (Oryza sativa L.), table pea (Pisum sativum L.), and onion (Allium cepa L.) [7] due to their heavy demands in domestic, national, and international markets.

Nutrient concentrations in FYM are usually small and vary greatly depending upon source, conditions, and duration of storage. The $\mathrm{N}, \mathrm{P}$, and $\mathrm{K}$ contents of fresh FYM range widely from 0.01 to 1.9 percent on dry weight basis due to variable nature of manure production and storage $[8,9]$. Tandon [10] reported that on an average, well-rotted FYM contains 0.5 per cent $\mathrm{N}, 0.2$ per cent $\mathrm{P}_{2} \mathrm{O}_{5}$, and 0.5 per cent $\mathrm{K}_{2} \mathrm{O}$. Gaur [11] stated that an application of $25 \mathrm{tha}^{-1}$ of well-rotted FYM can add $112 \mathrm{~kg} \mathrm{~N}, 56 \mathrm{~kg} \mathrm{P}_{2} \mathrm{O}_{5}$, and $112 \mathrm{~kg}$ $\mathrm{K}_{2} \mathrm{O} \mathrm{ha}^{-1}$. Several researchers all over the world have shown various benefits of the application of FYM on soil properties and productivity of crops [12]. Farmers generally use straw of the harvested crop as animal feed or bedding. In most cases, straw is used as bedding to trap urine to increase $\mathrm{N}$ cycling. Wet straw and manures from the animal sheds are collected every day and stored or composted on the farmer's premises. The composted manure is applied either immediately or stored until the next crop season depending upon farmer's socioeconomic conditions. In particular, soil, water, and nutrient management strategies, such as reduced tillage and use of raised beds, that avoid the deleterious effects of puddling on soil structure and fertility, improve water- and nutrient-use efficiencies, and increase crop productivity, may be appropriate [13].

\section{Effect of Organic Nutrition on Crop Productivity}

Addition of organic matter in the soil is a well-known practice to increase crop yields. Sharma and Mitra [14] reported that the application of organic materials increased grain and straw yield of rice. Ranganathan and Selvaseelan [15] found that application of spent mushroom and rice straw compost though comparable with FYM increased rice grain yields by 20 per cent over NPK fertilizer. Singh et al. [16] reported that the application of $7.5 \mathrm{t} \mathrm{FYM} \mathrm{ha}{ }^{-1}$ produced significantly more grain, and straw yields over unfertilized fields. All of the yield attributing characters of rice increased with increasing rates of FYM. Organic farming with dhaincha (Sesbania aculeata L.) made considerable improvement in grain yield of rice and Chickpea [17, 18]. Stockdale et al. [2] narrated the benefits of organic farming to developed nations (environmental protection, biodiversity enhancement, and reduced energy use and $\mathrm{CO}_{2}$ emissions) and to developing countries (sustainable resources use, increased crop yield without over reliance on costly inputs, and environmental and biodiversity protection).

Many researchers reported that in an organically managed field activity of earth worm is higher than in inorganic agriculture [19]. In the biodegradation process earthworms and microbes work together and produce vermicompost, which is the worm fecal matter with worm casts. Vermicompost provided macroelements such as $\mathrm{N}, \mathrm{P}, \mathrm{K}, \mathrm{Ca}$, and $\mathrm{Mg}$ and microelements such as $\mathrm{Fe}, \mathrm{Mo}, \mathrm{Zn}$, and $\mathrm{Cu}$ [20]. The vermicompost contained $0.74,0.97$, and 0.45 per cent nitrogen, phosphorus, and potassium, respectively [21].

In low-input agriculture, the crop productivity under organic farming is comparable to that under conventional farming. Tamaki et al. [22] reported that the growth of rice was better under continuous organic farming than with conventional farming. Agroeconomic study of practices of growing maize with compost and liquid manure top dressing in low-potential areas showed significantly better performance than those of current conventional farmer practices of a combined application of manure and mineral fertilizers. Maize grain yields were 11-17 per cent higher than those obtained with conventional practices [23].

Productivity of the crop during the initial year in an organically managed field is lower than in subsequent years as soil fertility levels increase over time as organic materials are added in the organic management system [24]. Similarly, Surekha [25] revealed that a gradual increase in grain yield with the use of organic fertilizers over a period of time was observed. Chan et al. [26] showed that the input of organic rice production in three different regions was 46,25 , and 22 per cent higher than conventional rice production, but rice yield was only 55,94 , and 82 per cent of conventional rice production, respectively. However, the cost of lower yield with higher inputs is compensated by the higher premium prices of organically crops in the markets [26].

Vegetables are highly responsive to organic sources of nutrients and profitable to farmers. Kalembasa [27] reported that vermicompost application of $15 \mathrm{~kg}$ per square meter gave the highest yield in tomato crop. Singh et al. [28] studied 
the response of chilli (Capsicum annuum $\mathrm{L}$.) to vermicompost and observed that the application of vermicompost increased the microbial activities. Vermicompost has a positive effect on the performance of crops due to a higher number of branches and fruits [28]. Tomar et al. [29] recorded the highest yield $\left(97 \mathrm{~g} \mathrm{plant}^{-1}\right.$ ) through vermicompost in brinjal (Solanum melongena L.). Kalembasa and Deska [30] obtained significantly higher yield of sweet pepper (Capsicum annum L. var. grossum) with vermicompost. Reddy et al. [31] recorded maximum plant height at harvest, days to first flowering, and branches plant ${ }^{-1}$ with the application of vermicompost $\left(10 \mathrm{tha}^{-1}\right)$. Similarly, Tomar et al. [29] reported that the application of vermicompost significantly increased leaf area in carrot (Daucus carota L.) plants.

Manjarrez et al. [32] conducted an experiment on chili receiving $1.25,2.0,3.0,4.0,6.0$, or $10.0 \mathrm{~g}$ of vermicompost $\mathrm{kg}^{-1}$ of soil under greenhouse conditions and reported that the foliar area and photosynthetic rate rose with increasing vermicompost application, and the highest photosynthetic rate $\left(12 \mu \mathrm{mol} \mathrm{CO}_{2} \mathrm{~m}^{-2} \mathrm{~s}^{-1}\right)$ was observed with vermicompost at $10 \mathrm{~g} \mathrm{~kg}^{-1}$ soil. Atiyeh et al. [33] observed that when 20 per cent commercial horticultural medium was replaced by vermicompost there was significant increase in plant height and root and shoot biomass in tomato crop. Ribeiro et al. [34] observed that dry matter content increased with increasing the vermicompost dose upto $400 \mathrm{~g} \mathrm{~kg}^{-1}$ soil in sweet pepper cv. Nacional Ag. 506. Atiyeh et al. [33] conducted an experiment in which tomatoes were grown in a standard commercial greenhouse container medium (Metro-Mix 360, Manufacturer: Sun Gro Horticulture Canada Ltd., 770 Silver Street Agawam, MA, USA, 01001), considered as control, substituted with $10,20,30,40,50,60,70,80,90$, and 100 per cent (by volume) pig (Sus scrofa L.) manure vermicompost. They obtained highest marketable yield ( $5.1 \mathrm{~kg}$ per plant) with substitution of Metro-Mix 360 with 20 per cent vermicompost. Substitution of Metro-Mix 360 with 10, 20, and 40 per cent vermicompost reduced the proportion of fruit that were nonmarketable and produced more large size (diameter $>$ $6.4 \mathrm{~cm}$ ) than small size (diameter $<5.8 \mathrm{~cm}$ ) fruits. Shreeniwas et al. [35] conducted a field experiment on ridge gourd ( $L$ uffa acutangula L. Roxb.) and observed that the increasing levels of vermicompost $\left(0,5,10\right.$, and $\left.15 \mathrm{tha}^{-1}\right)$ increased the fruit weight and fruit volume. Rao and Sankar [36] observed that the effect of organic manure on leaf number, leaf area index, dry matter production, and other growth characters was significantly better than those of inorganic fertilizer in brinjal.

Samawat et al. [37] reported that vermicompost had a significant effect on root and fruit weight of tomatoes. In 100 percent vermicomposted treatment, fruit, shoot, and root weights were three, five, and nine times, respectively more than control. Where vermicompost was applied at at $5 \mathrm{tha}^{-1}$ or at $10 \mathrm{tha}^{-1}$, increased shoot weight and leaf area of pepper plants (Capsicum annuum L.) compared to inorganic fertilizers [38]. Choudhary et al. [39] obtained the highest yield and available $\mathrm{N}$ of tomato cv. S-22 and cabbage (Brassica oleracea L.var. capitata) cv. Golden Acre with vermicompost at $200 \mathrm{~g} /$ plant $+\mathrm{FYM}$ at $250 \mathrm{~g} /$ plant, while maximum $\mathrm{K}$ and soil organic carbon was obtained with vermicompost at the rate of $100 \mathrm{~g} \mathrm{plant}^{-1}+\mathrm{FYM}$ at $500 \mathrm{~g} \mathrm{plant}^{-1}$. Hashemimajd et al. [40] revealed that the treatment vermicompost produced from raw dairy manure (RDM) along with some other compost (sewage sludge + rice hull) assimilated higher shoot and root dry matter (DM) of tomatoes than the control (soil + sand).

Patil et al. [41] reported that total potato (Solanum tuberosum L.) tubers yield was significantly higher with the application of vermicompost at $4 \mathrm{tha}^{-1}$ and FYM at $25 \mathrm{tha}^{-1}$. Sawicka et al. [42] reported that the cultivation system had the strongest effect on the share of commercial potato tubers and tubers of a diameter of $4-6 \mathrm{~cm}$ in the total yield. Haase et al. [43] suggested that tubers from organic potato cropping may be expected to have sufficiently high tuber dry matter concentrations (19\%) for processing into French fries without impairing the texture of the fries when concentration exceeds $23 \%$. Dry matter concentration of tubers for crisps (cv. Marlen) fell short of the required minimum of $22 \%$ when a combined $\mathrm{N}$ and $\mathrm{K}$ fertilizer was applied. Mourao et al. [44] found that organically grown potato $\mathrm{cv}$. Virgo yielded $66 \%$ of the conventional crop, whereas Raja yielded $46.6 \%$. The nitrogen uptake of organic crop (tubers and foliage) was $37.0 \mathrm{~kg} / \mathrm{ha}$ for Raja and $50.5 \mathrm{~kg} / \mathrm{ha}$ for Virgo compared to that of $21.1 \%$ and $27.8 \%$ of nitrogen uptake, respectively, with mineral fertilizer.

Addition of organic amendments and casting of earthworms to soil also proved effective in controlling diseases in pea (Pisum sativum L.), mustard (Brassica juncea L. Coss.), and chickpea (Cicer arietinum L.) during winter season. Nitrogen, phosphorus, potassium, calcium, and magnesium accumulation also increased with increasing doses of vermicompost as well as with fertilizers [45]. Singh [46] observed that the application of vermicompost at 13$20 \mathrm{q} \mathrm{ha}^{-1}$ increased yield of pea $\left(23.62 \mathrm{q} \mathrm{ha}^{-1}\right)$ and groundnut (Arachis hypogaea L.) $\left(12.16 \mathrm{q} \mathrm{ha}^{-1}\right)$. The principal findings of Jat and Ahlawat [47] revealed that the application of $3 \mathrm{t}$ vermicompost $\mathrm{ha}^{-1}$ to chickpea improved dry matter accumulation, grain yield, and grain protein content in chickpea, soil nitrogen and phosphorus and bacterial count, dry fodder yield of succeeding maize (Zea mays L.), and total nitrogen and phosphorus uptake by the cropping system over no vermicompost. Baswana and Rana [48] reported that the highest pod yield ( $93.96 \mathrm{q} / \mathrm{ha}$ ) of pea was recorded when farm yard manure $\left(1 \mathrm{tha}^{-1}\right)+$ poultry manure $\left(1 \mathrm{tha}^{-1}\right)$ along with mulch treatment was applied followed by farm yard manure $\left(2 \mathrm{tha}^{-1}\right)+$ biofertilizers with mulch treatment. Similar trend was also observed for biological yield and harvest index.

Dayal and Agarwal [49] observed that the seed yield of sunflower (Helianthus annus L.) was increased with the higher rate of vermicompost $\left(10 \mathrm{tha}^{-1}\right)$; the best combination was $5 \mathrm{tha}^{-1}$ vermicompost. Somasundaram et al. [50] reported that the study revealed that increased soluble protein content and nitrogenase activity of maize, sunflower, and green gram (Vigna radiata L.) was estimated with biogas slurry. Increased nitrogen accumulation at all growth stages on maize, sunflower, and green gram was observed under biogas slurry with panchagavya. Higher yield of maize and sunflower was recorded under biogas slurry with panchagavya 
(a preparation of 5 cow products (dung, urine, milk, ghee and curds)). Silwana et al. [51] reported the importance of organic manure and its long time usefulness in increasing productivity of maize-bean (Phaseolus vulgaris L.) intercrop for small-scale farmers in Eastern Cape of South Africa.

Sangakkara et al. [52] found that the organic matter incorporation increased soil water retention in soil and hence enhanced root growth, culminating in high yields of maize. The impact was greater in maize than in cowpea, especially with gliricidia leaves. Seo and Lee [53] reported that soil organic nitrogen increased considerably by hairy vetch. Dry matter yields of maize increased more in hairy vetch than ammonium nitrate with $\mathrm{N}$ rates over $160 \mathrm{~kg} \mathrm{ha}^{-1}$. Adiku et al. [54] revealed that the fertilized maize-grass and maizepigeon pea (Cajanus cajan L. Millspaugh) rotations were identified as those that sustained relatively high maize yields, returned large residue amounts to the soil, and minimized soil carbon loss.

Oliveira et al. [55] reported that the highest average head weight (700 g) and yield ( $38 \mathrm{t} \mathrm{ha}^{-1}$ ) in cabbage cv. Matsukaze was produced with the application of earthworm compost at 27 and $29 \mathrm{tha}^{-1}$, respectively. Datta et al. [56] confined that the inoculation of seed with Rhizobium leguminosarum bv. phaseoli and incorporation of FYM one week before sowing of rajmash (Phaseolus vulgaris L.) increased yield. Similarly, inoculation of seed enhanced $\mathrm{N}$ fixation and incorporation of FYM left a net positive balance of 42 and $84 \mathrm{~kg} \mathrm{~N}$, respectively, with regards to control (no seed inoculation and no FYM incorporation in soil). A higher accumulation rate of available $\mathrm{N}$ at all the growth stage of rajmash was observed with incorporation of FYM and inoculation of seed over control (no seed inoculation and no FYM incorporation in soil).

In all four of the years studied, the organic and conventional farming systems did not show significant differences in marketable yields for any vegetable crops, namely, tomato, bean, cabbage, and zucchini (Cucurbita pepo L.). The yields in organic farming were 10 per cent and 3 per cent, respectively, higher than conventional farming [57].

Sarangthem and Salam [58] reported that the application of decomposed urban waste with total nitrogen $0.58-$ 1.9 per cent, available phosphorus $0.45-0.67$ per cent, and available potash 1.4-1.8 per cent increased the yield of bean to $228 \mathrm{gm} /$ pot from $53 \mathrm{gm} /$ pot. The response on growth and yield of bean ( $228 \mathrm{~g} / \mathrm{pot}$ ) was recorded higher in the decomposed manure enrich with vermiculture. Renuka and Sankar [59] reported in tomato that the yield increased two and half times with the application of organic manures in comparison with inorganic fertilizer (18.44 tonnes). Likewise, Samawat et al. [37] reported that vermicompost had a significant effect on the number of fruits in tomato. In 100 percent vermicomposted treatment, fruit numbers were four times more than the control treatment. Arancon et al. [38] reported that when vermicompost applied at $5 \mathrm{tha}^{-1}$ or $10 \mathrm{tha}^{-1}$, the marketable tomato yield in all vermicompost treated plots were considerably greater than yield from the inorganic fertilizer plots. The total and marketable fruit yield of pepper also increased with vermicompost compared with inorganic fertilizers. Thanunathan et al. [60] reported that soil + mine spoil + coir pith vermicompost $(1: 1: 1)$ significantly increased plant height, number of leaf, and root length in onion (Allium cepa L.). Lopes et al. [61] reported that the application of vermicompost at $10 \mathrm{tha}^{-1}$ significantly increased nodulation and dry matter yield of cowpea (Vigna sinensis L.) over its lower levels, namely, 0 and $5 \mathrm{tha}^{-1}$.

\section{Effect of Organic Nutrition on Quality Parameters of Crops}

Yadav and Vijayakumari [62] carried out an experiment to assess the effect of vermicomposted vegetable waste on the biochemical characters of chilli and found that the protein was higher at $60\left(113 \mathrm{mg} \mathrm{g}^{-1}\right)$ and $90 \mathrm{DAS}\left(79 \mathrm{mg} \mathrm{g}^{-1}\right)$. The carbohydrate content was higher in vermicomposted treatment at 60 DAS $\left(15.34 \mathrm{mg} \mathrm{g}^{-1}\right)$. Chlorophyll $\left(2.61 \mathrm{mg} \mathrm{g}^{-1}\right)$ and total chlorophyll $\left(3.62 \mathrm{mg} \mathrm{g}^{-1}\right)$ contents were observed at $60 \mathrm{DAS}$, while chlorophyll a $\left(1.01 \mathrm{mg} \mathrm{g}^{-1}\right)$ was higher at 90 DAS as compared to inorganic fertilizers. In another experiment, Haase et al. [43] suggested that tubers from organic potato cropping may be expected to have sufficiently high tuber dry matter concentrations (19 per cent) for processing into French fries without impairing the texture of the fries when concentrations exceed 23 per cent. Similarly, application of FYM at $10 \mathrm{tha}^{-1}$ alone increased the economic yield and quality parameters like hulling percentage, milling percentage, and protein and amylose content of rice cv. Saket4 [63].

Mourao et al. [44] found that organically grown potatocv. Virgo yielded 66 per cent of the conventional crop, whereas Raja yielded 47 per cent. The nitrogen uptake of organic crop (tubers and foliage) was $37.0 \mathrm{~kg} / \mathrm{ha}$ for Raja and $50.5 \mathrm{~kg} / \mathrm{ha}$ for Virgo, respectively, 21 and 28 per cent of nitrogen uptake by same cultivars grown with mineral fertilizer. Although foliage nitrogen content was increased for the conventional crops, difference between $\mathrm{N}$ content of organic and conventional tubers were not significant, as well as for $\mathrm{K}, \mathrm{Ca}$, and $\mathrm{Mg}$. Maheswari et al. [64] studied the effect of foliar organic fertilizers on the quality and economics of chilli and observed the highest ascorbic acid content (175.23 mg/100 g) with vermiwash : water at $1: 5$ ratio.

\section{Effect of Organic Nutrition on Soil Fertility}

Minhas and Sood [65] also reported that the organic matter after decomposition release macro- and micronutrients to the soil solution, which becomes available to the plants, resulting in higher uptake. Organic farming was capable of sustaining higher crop productivity and improving soil quality and productivity by manipulating the soil properties on long term basis. It was reported that organic and low-input farming practices after 4 years led to an increase in the organic carbon, soluble phosphorus, exchangeable potassium, and $\mathrm{pH}$ and also the reserve pool of stored nutrients and maintained relativity stable EC level $[66,67]$.

Normal composting takes a long time leading to considerable loss of organic materials as $\mathrm{CO}_{2}$ or does not contribute to the organic pool [68]. Bulluck et al. [69] reported that 
the use of compost raised soil $\mathrm{pH}$ from 6.0 without compost to 6.5 with compost and reduced the broadleaf weed population by 29 per cent and grassy weed population by 78 per cent. Degradation of soil organic matter reduced nutrient supplying capacity, especially, on soils with high initial soil organic matter content in rice-wheat cropping system [70]. Organic farming improved organic matter content and labile status of nutrients [71] and also soil physicochemical properties. Addition of carbonaceous materials such as straw, wood, bark, sawdust, or corn cobs helped the composting characteristics of a manure. These materials reduced water content and raised the $\mathrm{C}: \mathrm{N}$ ratio. However, under Indian conditions, joint composting of the manure slurries with plant residues was more viable and profitable than its separate composting. Use of FYM and green manure maintained high levels of $\mathrm{Zn}, \mathrm{Fe}, \mathrm{Cu}$, and $\mathrm{Mn}$ in rice-wheat rotation [72].

Laxminarayana and Patiram [73] concluded that the decline in soil reaction might be due to organic compounds added to the soil in the form of green as well as root biomass which produced more humus and organic acids on decomposition. Urkurkar et al. [74] reported that supply of 100 per cent nitrogen, that is, $120 \mathrm{~kg} / \mathrm{ha}$ for rice and $150 \mathrm{~kg} / \mathrm{ha}$ for potato in a rice-potato cropping system $1 / 3$ each from cow dung manure, neem cake, and composed crop residue appreciably increased the organic carbon $\left(6.3 \mathrm{~g} \mathrm{~kg}^{-1}\right)$ over initial value $\left(5.8 \mathrm{~g} \mathrm{~kg}^{-1}\right)$ as compared to supply from inorganic fertilizers alone. However, availability of phosphorus and potassium did not show any perceptible change after completion of five cropping cycles under organic as well as integrated nutrient approaches.

\section{Effect of Organic Nutrition on Soil Biological Properties}

Compost contains bacterial, actinomycetes, and fungi; hence, a fresh supply of humic material not only added microorganisms but also stimulated them $[75,76]$. Besides, compost played an important role in control of plant nematodes and in mitigating the effect of pesticides through sorption. Sorption is the most important interaction between soil/organic matter and pesticides and limits degradation as well as transport in soil. Pesticides bound to soil organic matter or clay particles are less mobile, bioavailable but also less accessible to microbial degradation and thus more persistent [77-79]. Composting material added plenty of carbon and thus increased heterotrophic bacteria and fungi in soil and further increased the activity of soil enzymes responsible for the conversion of unavailable to available form of nutrients. The application of FYM with rhizobium and coinoculation of PSB with rhizobium augmented soybean (Glycine $\max$ L. Merr.) production [80].

Agricultural practices have had an impact on soil biophysiochemical properties. Densities of bacteria, protozoa, nematodes, and arthropods in soils under organic farming were higher than under conventional farming [81]. Bulluck et al. [82] reported that organic fertility amendments enhanced beneficial soil microorganisms, reduced pathogen population, total carbon, and cation exchange capacity, and lowered down bulk densities, thus improved soil quality.

The National Academy of Agricultural Sciences (NAAS) recommended a holistic approach involving integrated nutrient management (INM), integrated pest management (IPM) for enhanced input use efficiency, and adoption of region specific promising cropping systems as an alternative organic farming strategy for India and to begin with the practice of organic farming should value crops like spices, medicinal plants, fruits, and vegetables [83].

Singh and Bohra [84] reported that rice-pea-black gram (Vigna mungo L.) cropping system recorded higher population of bacteria, actinomycetes, and fungi than rice-wheat cropping system. Field experiment conducted with P solubilizers like Aspergillus awamori, Pseudomonas striata, and Bacillus polymyxa significantly increased the yield of various crops like wheat, rice, cowpea (Vigna sinensis L.), and so forth in presence of rock phosphate and saved $30 \mathrm{Kg} \mathrm{P}_{2} \mathrm{O}_{5} \mathrm{ha}^{-1}$ with the use of phosphate solubilizing microorganisms. Vegetable crops, in general, responded better to Azotobacter inoculation than other field crops. Nevertheless, yield increase in case of wheat, maize, jowar (Sorghum bicolor L. Moench), cotton (Gossypium spp.), and mustard crop using Azotobacter chrooccocum culture was 0-31 per cent higher than control [85].

In low-input agriculture, the crop productivity under organic farming is comparable to conventional farming. Integrated use of rice straw compost + Azotobacter and PSB was found better than rice straw alone [86]. Azotobacter produced growth promoting substances which improved seed germination and growth with extended root system. It also produced polysaccharides which improved soil aggregation [87]. Seed inoculation of chickpea with rhizobium + PSB (phosphate solubilising bacteria) increased dry matter accumulation, grain yield, and grain protein content in chickpea, dry fodder yield of succeeding maize, and total nitrogen and phosphorus uptake by the cropping system over no inoculation and inoculation with rhizobium alone.

\section{Conclusion}

Organic farming can provide quality food without adversely affecting the soil's health and the environment. There is need to identify suitable crops/products on regional basis for organic production that has international market demands. The whole region as such cannot afford to go for organic at a time because of its commitments to insure food and nutritional security. This will provide ample opportunity for employment and bring prosperity and peace in the region.

\section{References}

[1] A. Howard, An Agricultural Testaments, Oxford University Press, 1940.

[2] E. A. Stockdale, N. H. Lampkin, M. Hovi et al., "Agronomic and environmental implications of organic farming systems," Advances in Agronomy, vol. 70, pp. 261-327, 2001. 
[3] P. K. Chhonkar, "Organic farming myth and reality," in Proceedings of the FAI Seminar on Fertilizer and Agriculture Meeting the Challenges, New Delhi, India, December 2002.

[4] P. K. Sofia, R. Prasad, and V. K. Vijay, "Organic farmingtradition reinvented," Indian Journal of Traditional Knowledge, vol. 5, no. 1, pp. 139-142, 2006.

[5] S. Chandra and S. K. Chauhan, "Prospects of organic farming in India," Indian Farming, vol. 52, no. 2, pp. 11-14, 2004.

[6] K. K. M. Nambiar, P. N. Soni, M. R. Vats, D. K. Sehgal, and D. K. Mehta, "AICRP on long term fertilizer experiments," Annual Reports 1987-88 and 1988-89, IARI, New Delhi, India, 1992.

[7] S. Kalyan, "Development of sustainable farming system model for the Irrigated agro-ecosystem of Eastern UP, ICAR, Adhoc project," Final Annual Report, Department of Agronomy, Institute of Agricultural Science, Banaras Hindu University, Varanasi, India, 2005.

[8] A. Inoko, "Compost as source of plant nutrients," in Organic Matter and Rice, S. Banta and C. V. Mendoza, Eds., pp. 137-146, IRRI, Los Banos, Philippines, 1984.

[9] Z. I. Zhu, C. Q. Liu, and B. F. Jiang, "Mineralization of organic nitrogen, phosphorus and sulphur in some paddy soils in China," in Organic Matter and Rice, pp. 259-272, IRRI, Los Banos, Philippines, 1984.

[10] H. L. S. Tandon, "Fertilizers and their integration and organics and bio-fertilizers," in Fertilizers, Organic Manures, Recyclable Wastes and Bio-Fertilizers, H. L. S. Tandon, Ed., pp. 32-36, FDCO, New Delhi, India, 1992.

[11] A. C. Gaur, "Bulky organic manures and crop residues," in Fertilizer Organic Manures Recyclable Wastes and Bio-Fertilizers, H. L. S. Tandon, Ed., Fertiliser Development and Consultation Organisation, New Delhi, India, 1992.

[12] R. T. Prabhakar, M. Umadevi, and R. P. Chandrasekhar, "Effect of fly ash and farm yard manure on soil properties and yield of rice grown on an inceptisol," Agricultural Science Digest, vol. 30, no. 4, pp. 281-285, 2010.

[13] J. Timsina and D. J. Connor, "Productivity and management of rice-wheat cropping systems: issues and challenges," Field Crops Research, vol. 69, no. 2, pp. 93-132, 2001.

[14] A. R. Sharma and B. N. Mitra, "Complementary effect of organic material in rice-wheat crop sequence," The Indian Journal of Agricultural Sciences, vol. 60, no. 3, pp. 163-168, 1990.

[15] D. S. Ranganathan and D. A. Selvaseelan, "Mushroom spent rice straw compost and composted coir pith as organic manures for rice," Journal of the Indian Society of Soil Science, vol. 45, no. 3, pp. 510-514, 1997.

[16] G. Singh, O. P. Singh, R. A. Yadava, P. P. Singh, and R. Nayak, "Response of rice (Oryza sativa) varieties to nitrogen levels in flash flood conditions," Indian Journal of Agronomy, vol. 43, no. 3, pp. 506-510, 1998.

[17] K. N. Singh, B. Prasad, and S. K. Sinha, "Effect of integrated nutrient management on a Typic Haplaquant on yield and nutrient availability in a rice-wheat cropping system," Australian Journal of Agricultural Research, vol. 52, no. 8, pp. 855858, 2001.

[18] K. N. Singh, I. P. Sharma, and V. C. Srivastava, "Effect on FYM fertilizer and plant density on productivity of rice-what sequence," Journal of Research, Birsa Agricultural University, vol. 13, no. 2, pp. 159-162, 2001.

[19] C. A. Edwards and J. R. Lofty, "The invertebrate fauna of the Park Grassplots. I: soil fauna," Rothamsted Report, part 2, pp. 133-154, 1974.
[20] K. Amir and I. Fouzia, "Chemical nutrient analysis of different composts (Vermicompost and Pitcompost) and their effect on the growth of a vegetative crop Pisum sativum," Asian Journal of Plant Science and Research, vol. 1, no. 1, pp. 116-130, 2011.

[21] M. Pal, Basics of Agriculture, Jain Brothers, New Delhi, India, 2002.

[22] M. Tamaki, T. Itani, and H. Nakano, "Effects of organic ad inorganic fertilizers on the growth of rice plants of rice plants under different light intensities," Japanese Journal of Crop Science, vol. 71, no. 4, pp. 439-445, 2002.

[23] D. D. Onduru, J. M. Diop, E. Van der Werf, and A. De Jager, "Participatory on-farm comparative assessment of organic and conventional farmers' practices in Kenya," Biological Agriculture and Horticulture, vol. 19, no. 4, pp. 295-314, 2002.

[24] S. K. Yadav, S. Yogeshwar, M. K. Yadav, B. Subhash, and S. Kalyan, "Effect of organic nitrogen sources on yield, nutrient uptake and soil health under rice (Oryza sativa) based cropping sequence," Indian Journal of Agricultural Sciences, vol. 83, no. 2, pp. 170-175, 2013.

[25] K. Surekha, "Nitrogen-release pattern from organic sources of different $\mathrm{C}: \mathrm{N}$ ratios and lignin content, and their contribution to irrigated rice (Oryza sativa)," Indian Journal of Agronomy, vol. 52, no. 3, pp. 220-224, 2007.

[26] K. Y. Chan, C. Dorahy, T. Wells et al., "Use of garden organic compost in vegetable productionunder contrasting soil $\mathrm{P}$ status," Australian Journal of Agricultural Research, vol. 59, no. 4, pp. 374-382, 2008.

[27] D. Kalembasa, "The effects of vermicompost on the yield and chemical composition of tomato," Zeszyty Problemowe Postępów Nauk Rolniczych, vol. 437, pp. 249-252, 1996.

[28] J. Singh, S. S. Bhat, M. R. Sudharshan, Jasvir-Singh, and S. Sreekrishna-Bhat, "Performance of Scotch Bonnet chilli in Karnataka and its response to vermicompost," Indian Cocoa, Arecanut \& Spices Journal, vol. 21, pp. 9-10, 1997.

[29] V. K. Tomar, R. K. Bhatnagar, and R. K. Palta, "Effect of vermicompost on production of brinjal and carrot," Bhartiya Krishi Anusandhan Patrika, vol. 13, no. 3-4, pp. 153-156, 1998.

[30] S. Kalembasa and J. Deska, "The possibility of utilizing vermicompost in the cultivation of radish and paprika," Annals of Agricultural University of Poznan, vol. 27, pp. 131-136, 1998.

[31] R. Reddy, M. A. N. Reddy, Y. T. N. Reddy, N. S. Reddy, and M. Anjanappa, "Effect of organic and inorganic sources of NPK on growth and yield of pea," Legume Research, vol. 21, no. 1, pp. 5760, 1998.

[32] Manjarrez, M. J. Martinez, R. Ferrera Cerrato, and M. C. Gonzalez Chavez, "Effect of vermicompost and mycorrhizal fungi on growth and photosynthetic rate of chilli," Terra, vol. 17, no. 1, pp. 9-15, 1999.

[33] R. M. Atiyeh, N. Arancon, C. A. Edwards, and J. D. Metzger, "Influence of earthworm-processed pig manure on the growth and yield of greenhouse tomatoes," Bioresource Technology, vol. 75, no. 3, pp. 175-180, 2000.

[34] L. G. Ribeiro, J. C. Lopes, F. S. Martins, and S. S. Ramalho, "Effect of organic fertilizer application on sweet pepper yield," Horticultura Brasileira, vol. 18, pp. 134-137, 2000.

[35] C. H. Shreeniwas, S. Muralidhar, and M. S. Rao, "Yield and quality of ridge gourd fruits as influenced by different levels of inorganic fertilizers and vermicompost," Annals of Agricultural Research, vol. 21, pp. 262-266, 2000.

[36] T. S. S. Rao and C. R. Sankar, "Effect of organic manures on growth and yield of brinjal," South Indian Horticulture, vol. 49, pp. 288-291, 2001. 
[37] S. Samawat, A. Lakzian, and A. Zamirpour, "The effect of vermicompost on growth characteristics of tomato," Agricultural Science and Technology, vol. 15, no. 2, pp. 83-89, 2001.

[38] N. Q. Arancon, C. A. Edwards, P. Bierman, J. D. Metzger, S. Lee, and C. Welch, "Effects of vermicomposts on growth and marketable fruits of field-grown tomatoes, peppers and strawberries, the 7 th international symposium on earthworm ecology, Cardiff, Wales, 2002," Pedobiologia, vol. 47, no. 5-6, pp. 731-735, 2003.

[39] R. S. Choudhary, A. Das, and U. S. Patnaik, "Organic farming for vegetable production using vermicompost and FYM in Kokriguda watershed of Orissa," Indian Journal of Soil Conservation, vol. 31, no. 2, pp. 203-206, 2003.

[40] K. Hashemimajd, M. Kalbasi, A. Golchin, and H. Shariatmadari, "Comparison of vermicompost and composts as potting media for growth of tomatoes," Journal of Plant Nutrition, vol. 27, no. 6, pp. 1107-1123, 2004.

[41] M. P. Patil, N. C. Hulamani, S. I. Athani, and M. G. Patil, "Response of tomato (Salanum tuberosum) cv. Kufri Chandramukhi to integrated nutrient management," Advances in Agricultural Research in India, vol. 8, pp. 135-139, 1997.

[42] B. Sawicka, P. Barbas, and J. Kus, "Variability of potato yield and its structure in organic and integrated crop production systems," Electronic Journal of Polish Agricultural Universities, vol. 10, no. 1, pp. 425-427, 2007.

[43] T. Haase, C. Schüler, N. U. Haase, and J. Heß, "Suitability of organic potatoes for industrial processing: effect of agronomical measures on selected quality parameters at harvest and after storage," Potato Research, vol. 50, no. 2, pp. 115-141, 2007.

[44] I. Mourao, L. M. Brito, and J. Coutinho, "Cultivating thefuture based-on science, volume-1: organic crop-production," in Proceedings of the 2nd Scientific Conference of the International Society of Organic Agriculture Research ISOFAR, held at the 16th IFOAM Organic World Conference in Cooperation with the International Federation of Organic Agriculture-Movements IFOAM and the Consorzio ModenaBio, pp. 596-599, International Society of Organic Agricultural Research (ISOFAR), Bonn, Germany, June 2008.

[45] S. C. Tripathi, D. S. Chauhan, R. K. Sharma, and O. P. Dhillon, "Productivity and economics of different wheat (Triticum aestivum) based cropping sequences," Indian Journal of Agronomy, vol. 44, no. 2, pp. 237-241, 1999.

[46] R. A. Singh, "Feasibility of vermi-farming in peanut (Arachis hypogaea)-vegetable pea (Pisum sativum) cropping system," Indian Journal of Agronomy, vol. 45, no. 2, pp. 257-262, 2000.

[47] R. S. Jat and I. P. S. Ahlawat, "Direct and residual effect of vermicompost, biofertilizers and phosphorus on soil nutrient dynamics and productivity of chickpea-fodder maize sequence," Journal of Sustainable Agriculture, vol. 28, no. 1, pp. 41-54, 2006.

[48] K. S. Baswana and M. K. Rana, "Effect of organic sources and biofertilizers on growth and yield of garden pea (Pisum sativum L)," Haryana Journal of Horticultural Sciences, vol. 36, no. 3-4, pp. 326-330, 2007.

[49] D. Dayal and S. K. Agarwal, "Response of sunflower genotypes (Helianthus annuus) to nutrient management," Indian Journal of Agricultural Sciences, vol. 69, no. 1, pp. 10-13, 1999.

[50] E. Somasundaram, M. A. Mohamed, K. Thirukkumaran, Chandrasekaran, K. Vaiyapuri, and K. Sathyamoorthi, "Biochemical changes, nitrogen flux and yield of crops due to organic sources of nutrients under maize based cropping system," Journal of Applied Sciences Research, vol. 3, pp. 1724-1729, 2007.
[51] T. T. Silwana, E. O. Lucas, and A. B. Olaniyan, "The effects of inorganic and organic fertilizers on the growth and development of component crops in maize/bean intercrop in Eastern Cape of South Africa," Journal of Food, Agriculture and Environment, vol. 5, no. 1, pp. 267-272, 2007.

[52] R. Sangakkara, P. Bandaranayake, U. Dissanayake, and J. N. Gajanayake, "Organic matter addition in organic farmingimpact on root development and yields in maize and cowpea over dry seasons," in Proceedings of the 2nd Scientific Conference of the International Society of Organic Agriculture Research (ISOFAR '08), held at the16th IFOAM Organic World Conference in Cooperation with the International Federation of OrganicAgriculture Movements IFOAM and the Consorzio ModenaBio, Modena, Italy, June 2008.

[53] J. Seo and H. J. Lee, "Mineral nitrogen effects of hairy vetch (Vicia villosa Roth) on maize (Zea mays L.) by green manure amounts," Journal of Agronomy, vol. 7, no. 3, pp. 272-276, 2008.

[54] S. G. K. Adiku, J. W. Jones, F. K. Kumaga, and A. Tonyigah, "Effects of crop rotation and fallow residue management on maize growth, yield and soil carbon in a savannah-forest transition zone of Ghana," Journal of Agricultural Science, vol. 147, no. 3, pp. 313-322, 2009.

[55] A. P. Oliveira, D. S. Ferreira, C. C. Casta, A. F. Silva, and E. V. Alves, "Utilization of cattle manure and earthworm compost in hybrid cabbage production," Horticulture Brasileira, vol. 13, pp. 70-73, 2001.

[56] N. Datta, M. C. Rana, and R. P. Sharma, "Effect of seed inoculation and farm yard manuring on nitrogen balance and yield in Rajmash (Phaseolus vulgaris)," Indian Journal of Plant Physiology, vol. 11, no. 1, pp. 108-112, 2006.

[57] V. Tabaglio, C. Gavzzi, and G. Nervo, "Cultivating the future based on science. Volume 1: organic crop production," in Proceedings of the 2nd Scientific Conference of the International Society of Organic Agriculture Research, held at the 16th IFOAM Organic World Conference in Cooperation with the International Federation of Organic Agriculture Movements (IFOAM) andthe-Consorzio ModenaBio, pp. 328-331, International Society of Organic Agriculture Research, Modena, Italy, June 2008.

[58] I. Sarangthem and J. S. Salam, "Recycling of the urban waste as manure on French bean (Phaseolus vulgaris) as test crop," Indian Journal of Agricultural Research, vol. 42, no. 2, pp. 124127, 2008.

[59] B. Renuka and C. R. Sankar, "Effect of organic manures on growth and yield of tomato," South Indian Hort, vol. 49, pp. 216$219,2001$.

[60] K. Thanunathan, S. Natarajan, R. Sentikumar, and K. Asulmurogan, "Effect of different sources of organic amendments on growth and yield of onion in mine spoil," Madras Agricultural Journal, vol. 84, no. 7, pp. 382-384, 1997.

[61] A. J. Lopes, N. P. Stamford, M. V. B. Figueired, N. A. Burity, and E. B. Ferraz, "Effect of vermicompost, mineral nitrogen and mineralizing agent on $\mathrm{N}$ fixation and yield in cowpea," Revista Brasileira de Ciência to Solo, vol. 20, pp. 55-62, 1996.

[62] R. H. Yadav and B. Vijayakumari, "Impact of vermicompost on biochemical characters of Chilli (Capsicum annum)," Journal of Ecotoxicology and Environmental Monitoring, vol. 14, no. 1, pp. 51-56, 2004.

[63] K. G. Dixit and B. R. Gupta, "Effect of farmyard manure, chemical and bio-fertilizers on yield and quality of rice (Oryza sativa L.) and soil properties," Journal of the Indian Society of Soil Science, vol. 48, no. 4, pp. 773-780, 2000. 
[64] T. U. Maheswari, K. Haripriya, P. Poonkodi, and S. Kamala kannan, "Effect of foliar application of organic nutrients on some quality indices and economics of chilli (Capsicum annum L," Advances in Plant Sciences, vol. 17, no. 1, pp. 259-262, 2004.

[65] R. S. Minhas and A. Sood, "Effet of inorganic and organic on yield and nutrients uptake by three crops in rotation in aid alfisol," Journal of the Indian Society of Soil Science, vol. 42, pp. 27-260, 1994.

[66] M. S. Clark, W. R. Horwath, C. Shennan, and K. M. Scow, "Changes in soil chemical properties resulting from organic and low-input farming practices," Agronomy Journal, vol. 90, no. 5, pp. 662-671, 1998.

[67] A. C. Gaur, S. Nilkantan, and K. S. Dargan, Organic Manures, ICAR, New Delhi, India, 2002.

[68] N. S. Subba Rao, "Organic matter decomposition," in Soil Microbiology, pp. 255-270, Oxford \& IBH Publishing, New Delhi, India, 1999.

[69] L. R. Bulluck, M. Brosius, G. K. Evanylo, and J. B. Ristaino, "Organic and synthetic fertility amendments influence soil microbial, physical and chemical properties on organic and conventional farms," Applied Soil Ecology, vol. 19, no. 2, pp. 147160, 2002.

[70] R. L. Yadav, B. S. Dwivedi, and P. S. Pandey, "Rice-wheat cropping system: assessment of sustainability under green manuring and chemical fertilizer inputs," Field Crops Research, vol. 65, no. 1, pp. 15-30, 2000.

[71] S. Subbiah and K. Kumaraswamy, "Effect of manure-fertilizers on the yield and quality of rice and on soil fertility," Fertilizer News, vol. 45, no. 10, pp. 61-68, 2000.

[72] S. P. Singh, R. M. Kumar, and S. V. Subbaiah, "Effect of nitrogen and potassium application on grain yield of hybrid rice (Oryza sativa)," in Proceedings of the 2nd International Agronomy Congress, vol. 1, New Delhi, India, 2002.

[73] K. Laxminarayana and Patiram, "Effect of integrated use of inorganic, biological and organic manures on rice productivity and soil fertility in ultisols of Mizoram," Journal of Indian Society of Soil Science, vol. 54, no. 2, pp. 213-220, 2006.

[74] J. S. Urkurkar, S. Chitale, and A. Tiwari, "Effect of organic $\mathrm{v} / \mathrm{s}$ chemical nutrient packages on productivity, economics and physical status of soil in rice (Oryza sativa)-Potato (Solanum tuberosum) cropping system in Chhattisgarh," Indian Journal of Agronomy, vol. 55, no. 1, pp. 6-10, 2010.

[75] A. Balasubramanian, R. Siddaramappa, and G. Rangaswami, "Effect of organic manuring on the activities of the enzymes hydrolysing sucrose and urea and on soil aggregation," Plant and Soil, vol. 37, no. 2, pp. 319-328, 1972.

[76] A. C. Gaur, K. V. Sadasivam, O. P. Vimal, R. S. Mathur, and S. K. Kavimandan, "Studies on the humification of organic matter in a red Rakar soil," Zentralblatt fur Bakteriologie, vol. 128, no. 1, pp. 149-161, 1973.

[77] A. C. Gaur and S. K. Prasad, "Effect of organic matter and inorganic fertilizers on plant parasitic nematodes," Indian Journal of Entomology, vol. 32, pp. 186-188, 1970.

[78] S. K. Prasad, S. D. Mishra, and A. C. Gaur, "Effect of soil amendments on nematodes associated with wheat followed by mung and maize," Indian Journal of Entomology, vol. 34, pp. 307-311, 1972.

[79] A. C. Gaur, "All Indian coordinated project on microbiological decomposition and recycling of farm and city wastes," Project Report, Indian Council of Agricultural Research, Poona, India, 1975.
[80] K. N. Sharma and K. N. Namdeo, "Effect of bio-fertilizers and phosphorus on growth and yield of Soybean (Glycine max L. Merill)," Crop Research, vol. 17, no. 2, pp. 160-163, 1999.

[81] S. Wu, E. R. Ingham, and D. Hu, "Soil microfloral and faunal populations in an organic ecosystem in Oregon, USA," in Proceedings of the 17th World Congress of Soil Science, vol. 5, p. 1756, Queen Sirkit National Convention Centre, Bangkok, Thailand, August 2002.

[82] L. R. Bulluck III, M. Brosius, G. K. Evanylo, and J. B. Ristaino, "Organic and synthetic fertility amendments influence soil microbial, physical and chemical properties on organic and conventional farms," Applied Soil Ecology, vol. 19, no. 2, pp. 147$160,2002$.

[83] P. Bhattacharya and G. Chakraborty, "Current status of organic farming in India and other countries," Indian Journal of Fertilizers, vol. 1, no. 9, pp. 111-123, 2005.

[84] K. Singh and J. S. Bohra, "Net working project on diversification of rice wheat system through pulses and oilseeds," Project Report, UPCAR, 2009.

[85] S. T. Shende and R. Apte, "Azospirillum inoculation-a highly remunerative input for agriculture," in Proceedings of the National Symposium on Biological Nitrogen Fixation, pp. 532541, New Delhi, India, February 1982.

[86] S. Kalyan, "Integrated use of industrial and farm wastes with mineral and bio-activators for sustained rice productivity in rice based eco-system of Eastern Uttar Pradesh," First Annual Report, NATP, ICAR, New Delhi, India, 2003.

[87] A. C. Gaur, Handbook of Organic Farming and Biofertilizers, Ambica Book Publication, Jaipur, India, 2006. 


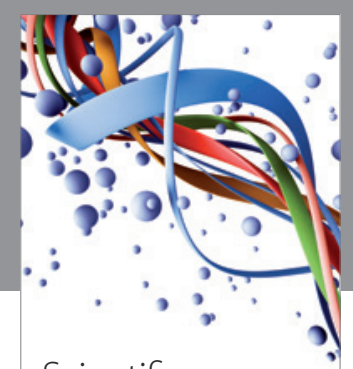

Scientifica
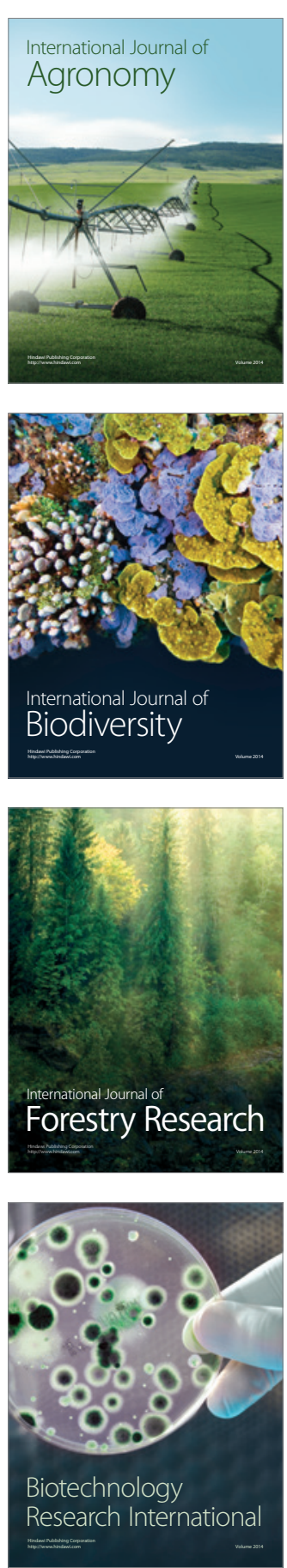
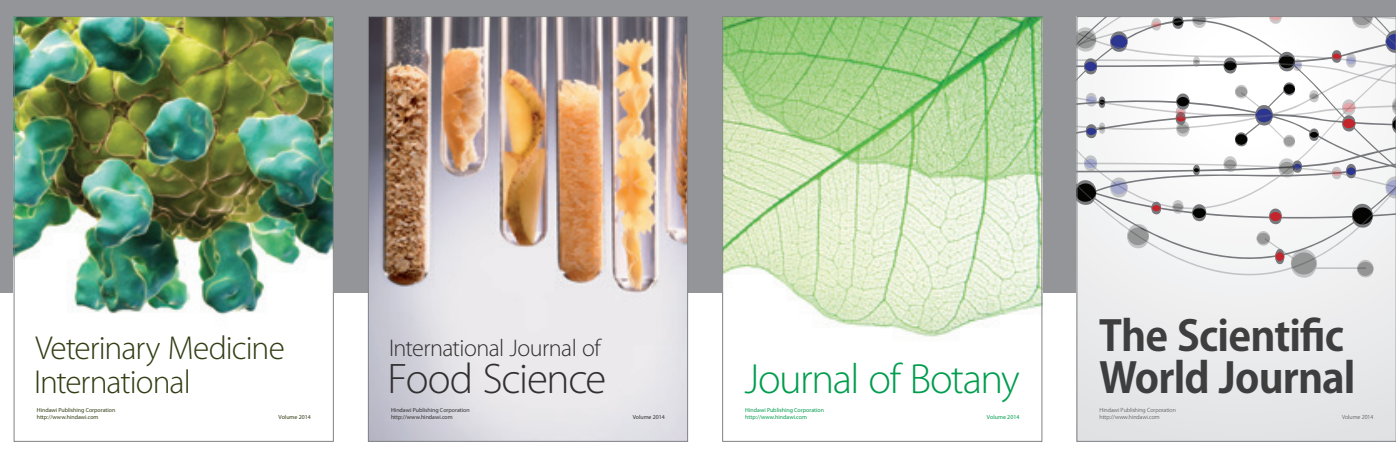

The Scientific World Journal
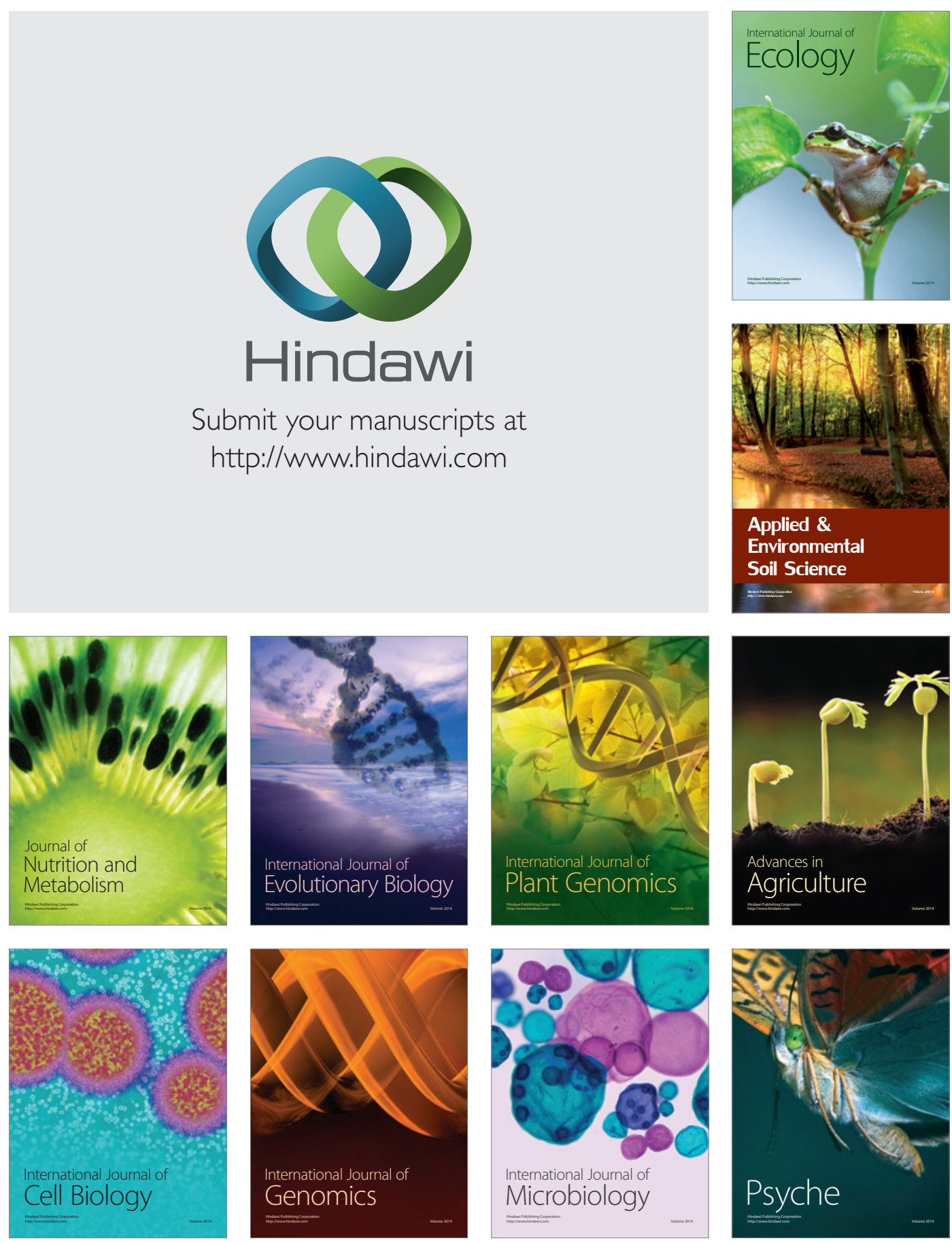